\title{
Evaluation of Different Hybrid Energy Potential in AL-Arish
}

\author{
Ahmed M. Attala \\ Department of Electrical Power \\ and Machines. \\ Faculty of Engineering-Ain \\ Shams University. \\ Cairo, Egypt
}

\author{
A. T. M. Taha \\ Department of Electrical Power \\ and Machines. \\ Faculty of Engineering-Ain \\ Shams University. \\ Cairo, Egypt
}

\author{
Ahmed.K.Ryad \\ Department of Electrical Power \\ and Machines. \\ Faculty of Engineering-Ain \\ Shams University. \\ Cairo, Egypt
}

\begin{abstract}
This paper presents the potential impact of various energy generation utilizing wind turbines, photovoltaic cell, fuel cell and diesel generation for AL-Arish, Sinai, Egypt. In addition to investigating the feasibility for each combination where they are simulated using Hybrid Optimization Modeling for Energy Renewable (HOMER) software to find the optimum size for each unit and its corresponding economics.
\end{abstract}

\section{Keywords}

HOMER Software, Wind Turbine, PV, Battery, Diesel Generator, Fuel Cell.

\section{INTRODUCTION}

Using fossil fuels like petroleum and coal as energy resources produce a bad effect on the environment in emission of harmful gases specially carbon dioxide as well as their high prices and these resources started depleting in the oilproducing countries [ $1 \rightarrow 3]$.

Renewable resources as wind and solar energy are clean, freely-available and permanent, although they are unpredictable. The combination of renewable resources is widely used as an alternative for fossil fuel resources, especially in remote sites where it's becoming more promising. Usually the hybrid combination consists of two or more resources, controller, converters and a storage system [4].

\section{HYBRID SYSTEM COMPONENTS}

The hybrid system after the prefeasibility study consists of the following components:

1) BWC Excel-R wind turbine.

2) CHSM 6610P-250 photovoltaic panel.

3) Trojan L16P Battery.

4) Converter.

5) Fuel Cell.

6) Diesel generator.

7) AL-Arish Load.

\subsection{Wind Turbine:}

In this simulation, Bergey Wind Power's BWC Excel-R model is considered. It has a rated capacity of $7.5 \mathrm{~kW}$ and provides $48 \mathrm{~V}$ DC as an output. Its initial cost is $\$ 28500$ and its replacement at $\$ 24500$ [5]. Annual operation and maintenance cost is $\$ 200$. Its lifetime is estimated at 20 years, a number from 1 unit to 10 is considered.

\subsection{Photovoltaic module:}

CHSM 6610P-250 photovoltaic panel is considered in the scheme, with initial and replacement cost \$ 265 with rated power 250 watt and rated voltage $30 \mathrm{~V}$ [6] sizes to be considered are $(0.250 .511 .522 .533 .544 .5055 .566 .510$ 2030405060 100) watts.

\subsection{Battery}

Trojan L16P Battery models (6 V, 360Ah, $1.075 \mathrm{kWh),} \mathrm{Cost}$ of one battery is $\$ 275$ and maintenance cost $\$ 3$ [7], a number of units considered are (102050100150200250 300).

\subsection{Converter}

For a $1 \mathrm{~kW}$ converter the installation and maintenance costs are taken as $\$ 1000$ and $\$ 10$, number of units to be considered (12345610203050100150 200) KW

\subsection{Fuel Cell}

A fuel cell is an energy conversion device, which converts the chemical energy of a fuel and oxidant, often hydrogen and oxygen, to electrical energy. Fuel cells are similar to batteries, however, unlike battery a fuel cell must be continuously provided with fuel, with initial and replacement cost $\$ 3000$ and $\$ 2700$ respectively, for $1 \mathrm{KW}$ size and operation and annual maintenance cost $\$ 0.02$ [8] sizes to be considered are (1 234567101520$)$ KW.

\subsection{Diesel generator.}

The diesel generator sizes to be considered in simulation vary from 3 to $7 \mathrm{~kW}$. Their initial costs and replacement cost are respectively $(2990,2400 \$),(3978,3200 \$),(4984,4000 \$)$, $(5981,4800 \$)$ and $(6978,5600 \$)$. Their operation and maintenance are of $0.05 \$ / \mathrm{h}$ [9] 


\subsection{AL-Arish Load:}

The annual peak load is $11 \mathrm{KW}$ with energy consumption of $85 \mathrm{kWh} /$ day and the daily profile of the load is shown in Fig. 1.

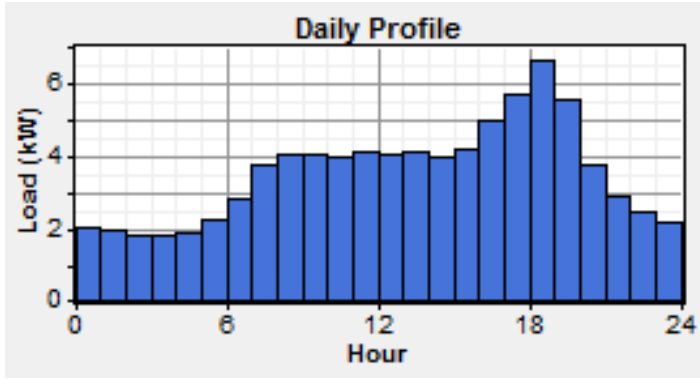

Fig.1: AL-Arish Load Profile.

\section{WIND AND SOLAR RESOURCES:}

The annual average wind speed and the annual average insolation level at AL-Arish is $5.29 \mathrm{~m} / \mathrm{s}$ and 5.71 $\mathrm{kWh} / \mathrm{m}^{2} /$ day, respectively. The monthly wind speed variation, the monthly clearness index and the daily radiation are shown in Fig. $(2,3)$ [10].

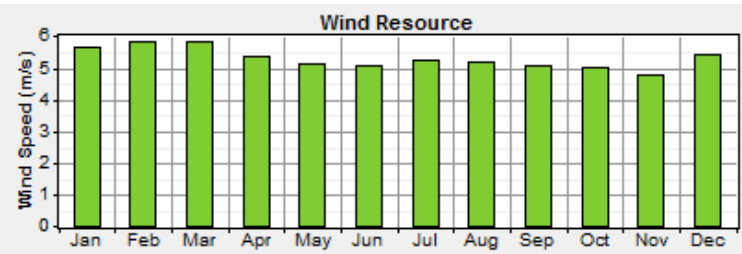

Fig.2: AL-Arish Wind Speed

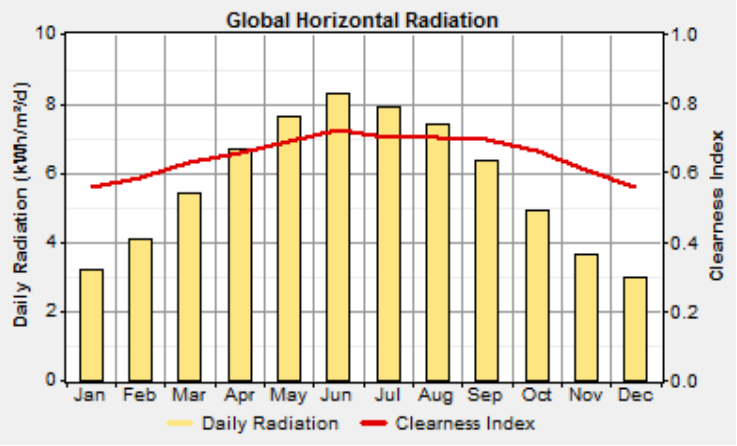

Fig.3: AL-Arish Solar Irradiance

\section{SIMULATION OF HYBRID SYSTEMS WITH HOMER SOFTWARE:}

HOMER software simulates the operation of the proposed system along the year by making an energy balance between the generation and the load to determine the feasible system architecture which meet the load demand under the site condition beside specifying the cost-effective combination based on the total net present cost [TNPC] which is the summation of all the costs and revenue all over the project life time which is assumed 25 years [11].

Where the cost of each element is given by:

$\mathrm{Ci}=\mathrm{Ni} *[\mathrm{CCosti}+\mathrm{RCosti} * \mathrm{Ki}+$ OMCosti $]$

$\mathrm{i}=$ PV, Wind Turbine, Diesel Generator, Fuel Cell, Battery and Converter.

Where $\mathrm{Ni}$ is the number/size of the system component, CCosti is the capital cost, RCosti is the replacement cost, $\mathrm{Ki}$ is the number of replacement, and OMCosti is operation and maintenance cost through the system operation.

Number of combinations are to be considered as follows:

1. Wind turbine, Batteries and Diesel generation.

2. PV panel, Batteries and Diesel generation.

3. Wind turbine, Batteries and PV panels.

4. Wind turbine, Batteries, PV panels and Diesel generation.

5. Wind turbine and Fuel cell

6. PV panels and Fuel cell

7. Wind turbine, PV panels and Fuel cell.

Then simulated using HOMER software to determine the most optimum combination for AL-Arish load.

\subsection{Wind and Diesel generation}

The Fig.4 shows Wind and Diesel System Design Using HOMER

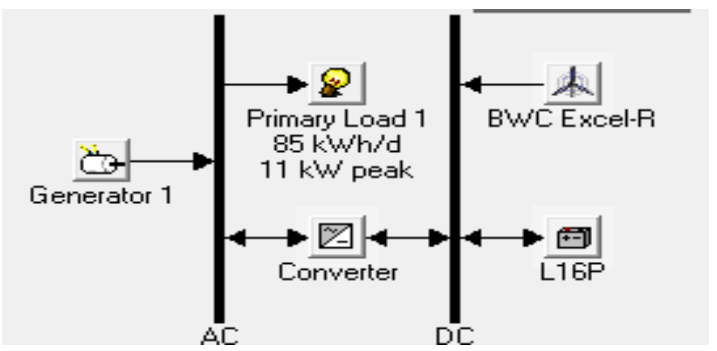

Fig.4: Wind and Diesel System.

The simulation results present the optimum combination: 1 wind turbine, $4 \mathrm{KW}$ generator, 10 batteries and $4 \mathrm{KW}$ converter as shown in Table. (1), with initial cost: 33,228 , operating cost: $7,208 \$$ year and cost of energy: $0.335 \$ / \mathrm{kWh}$, Fig (5) shows the energy yield of the optimum solution.

Table.1: Wind and Diesel Optimization Result.

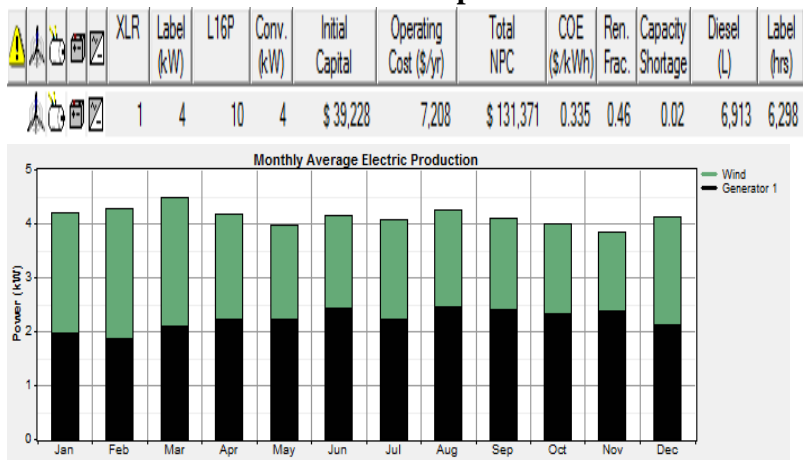

Fig.5: Wind and Diesel Electric Production 


\subsection{PV and Diesel generation}

The Fig.6 shows PV and Diesel System Design Using HOMER.

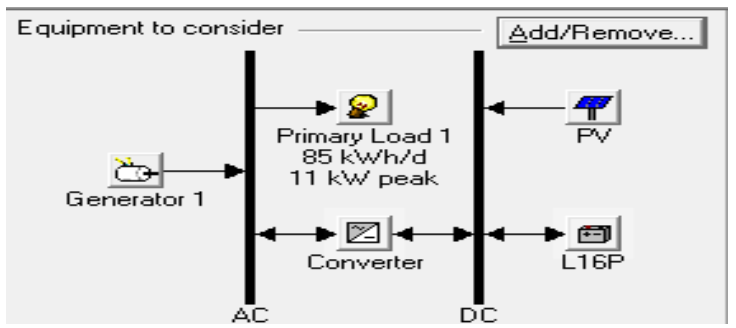

Fig.6: PV and Diesel System.

The simulation results present the optimum combination: $20 \mathrm{KW} \mathrm{PV}, 2 \mathrm{KW}$ generator, 50 battery unit and $6 \mathrm{KW}$ converter as shown in Table. (2) and Fig. (7) shows the energy yield of the optimum solution.

Table.2: Wind and PV Optimization Result

\begin{tabular}{|c|c|c|c|c|c|c|c|c|c|c|}
\hline 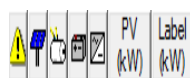 & & 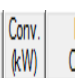 & $\begin{array}{l}\text { litital } \\
\text { Capoital }\end{array}$ & $\begin{array}{l}\text { Operding } \\
\text { Cost (Syr) }\end{array}$ & $\begin{array}{l}\text { Todal } \\
\text { NPC }\end{array}$ & $\left|\begin{array}{c}C O E \\
(S \mathrm{kWh})\end{array}\right|$ & 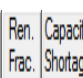 & & & \\
\hline & & & & & & & & & & \\
\hline
\end{tabular}

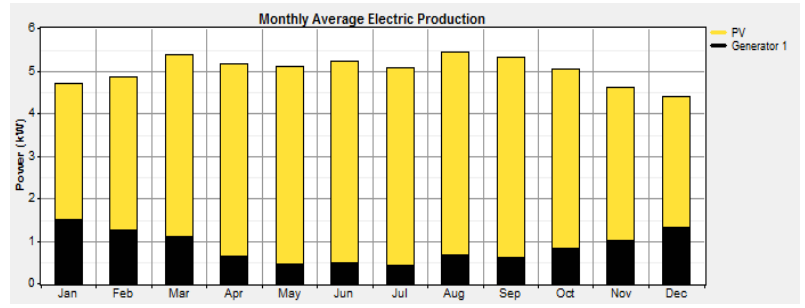

Fig.7: Wind and PV Electric Production

\subsection{Wind and $P V$.}

The Fig.8 shows Wind and PV System Design Using HOMER.

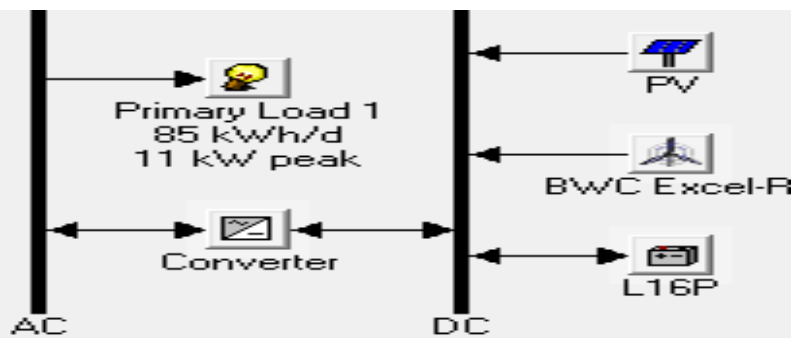

Fig.8: Wind and PV System
The simulation results present the optimum combination: $20 \mathrm{KW}, 1$ wind turbine, 50 battery unit and $10 \mathrm{KW}$ converter as shown in Table. (3), and Fig. (9) shows the energy yield of the optimum solution.

Table.3: Wind and PV Optimization Result

\begin{tabular}{|c|c|c|c|c|c|c|c|}
\hline 1)甲 & \begin{tabular}{l|l}
$X L R$ \\
\end{tabular} & LIGP & $\begin{array}{c}\text { Conv. } \\
\text { kWI }\end{array}$ & $\begin{array}{l}\text { Intiala } \\
\text { Capital }\end{array}$ & $\begin{array}{l}\text { Operding } \\
\text { Cost (Syr) }\end{array}$ & $\begin{array}{l}\text { Total } \\
\text { NPC }\end{array}$ & 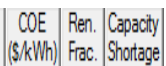 \\
\hline 单人网网 & 1 & 50 & 10 & $\$ 73,450$ & 305 & $\$ 115,7$ & 61.00 \\
\hline
\end{tabular}

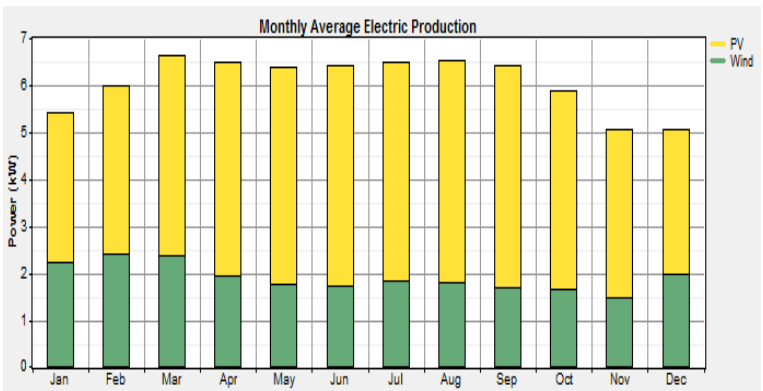

Fig.9: Wind and PV Electric Production.

\subsection{Wind, PV and Diesel}

The Fig.10 shows Wind, PV and System Design Using HOMER.

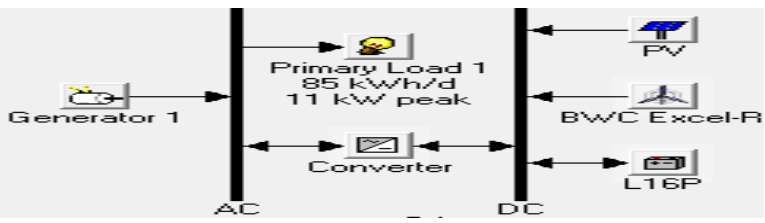

Fig.10: Wind, PV and Diesel System

The simulation results present the optimum combination: 11 KW PV, 1 wind turbine, 2KW generator, 30 battery unit and 6 KW converter as shown in Table. (4) and Fig. (11) shows the energy yield of the optimum solution.

Table.4: Wind, PV and Diesel Optimization Result

\begin{tabular}{|c|c|c|c|c|c|c|c|c|c|c|c|}
\hline 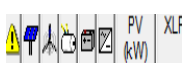 & LR $\mid \begin{array}{ll}\text { Labe } \\
\mathrm{kW}\end{array}$ & L16P & $\left|\begin{array}{l}\text { Conv. } \\
\text { kWM }\end{array}\right|$ & $\begin{array}{l}\text { Intidal } \\
\text { Caotata }\end{array}$ & $\begin{array}{l}\text { Operding } \\
\operatorname{Cos}(S / y)\end{array}$ & $\begin{array}{l}\text { Total } \\
\text { NPC }\end{array}$ & $\left|\begin{array}{c}C O E \\
(S k W h n\end{array}\right|$ & & Cappacty| & $\begin{array}{l}\text { Diesel } \\
\text { (L) }\end{array}$ & $\begin{array}{l}\text { Label } \\
(\text { hrs }\end{array}$ \\
\hline 网网 & & & & $\$ 56$ & & & & & & & \\
\hline
\end{tabular}

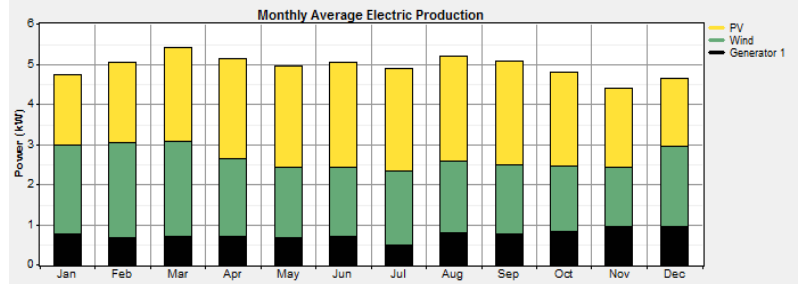

Fig.11: Wind, PV and Diesel Electric Production 


\subsection{Wind Turbine and Fuel Cell.}

The Fig.12 shows Wind and Fuel System Design Using HOMER.

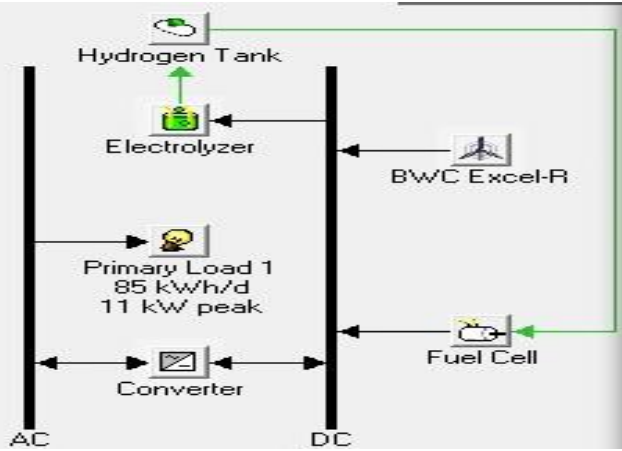

Fig.12: Wind and Fuel Cell System

The simulation results present the optimum combination: 6 BWC wind turbine, $6 \mathrm{KW}$ Fuel Cell, $10 \mathrm{KW}$ converter, 10 $\mathrm{KW}$ Electrolyzer and $20 \mathrm{~kg}$ hydrogen tank as shown in table (5) and Fig. (13) shows the energy yield of the optimum solution.

Table.5: Wind and Fuel Cell Optimization Result

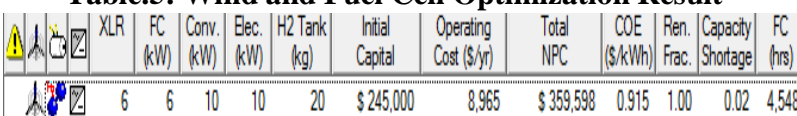

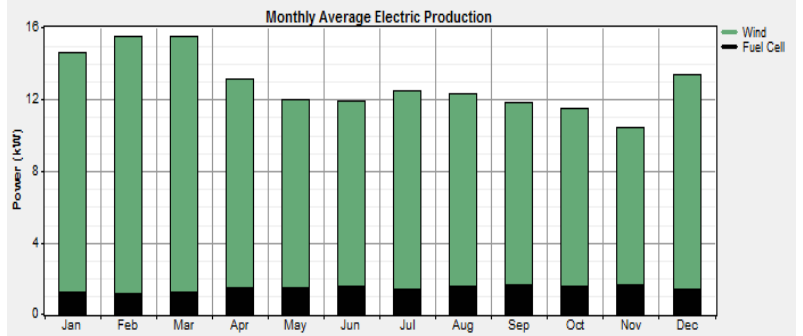

Fig.13: Wind and Fuel Cell Electric Production

\subsection{PV panels and Fuel cell.}

The Fig.14 shows PV and Fuel System Design Using HOMER.

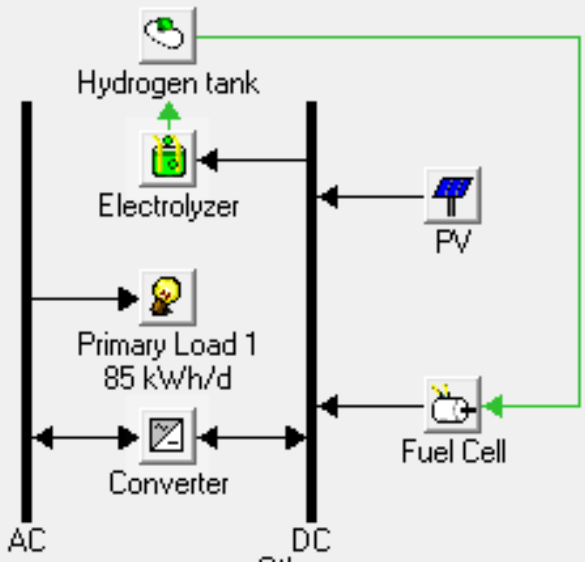

Fig.14: PV and Fuel Cell System

There is no optimum solution found
4.7. Wind turbine, PV panels and Fuel cell. The Fig.15 shows Wind, PV and Fuel System Design Using HOMER.

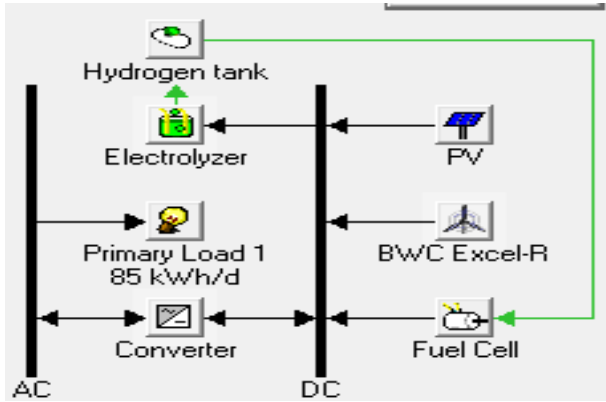

Fig.15: Wind, PV and Fuel Cell System

The simulation results present the optimum combination: 40 $\mathrm{KW}$ PV, 2 BWC wind turbine, $6 \mathrm{KW}$ Fuel cell, $10 \mathrm{KW}$ Converter (Inverter \& Rectifier), $10 \mathrm{KW}$ Electrolyzer and 10 Kg hydrogen tank as shown in table (6) and Fig. (16) Shows the energy yield of the optimum solution.

Table.6: Wind, PV and Fuel Cell System Optimization Result

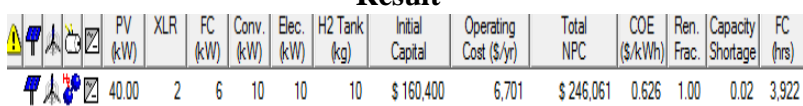

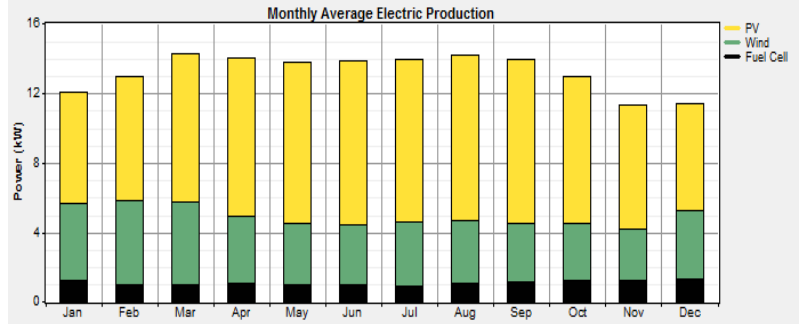

Fig.16: Wind, PV and Fuel Cell Electric Production

\section{LOAD SHEDDING}

Load Shedding is a preferred method of saving energy for the grid. During certain times of the day, or during emergencies, large consumers of electricity will reduce their electricity usage, thus reducing the load on the grid.

This can save the cost of having extra generators and reduce the cost of electricity for consumers.

For AL-Arish load a percentage of $20 \%$ of the peak load is reduced for the peak months (April, August) on the peak hour $(18: 00 \rightarrow 19: 00)$

\section{CONCLUSIONS}

The previous cases are summarized in table (7) showing the system architecture and economic value.

The results show that the combination including diesel generators (as: wind \&diesel, PV \& diesel and wind \& PV\& diesel) gives less net present cost than its corresponding combination with fuel cell (as: wind \&fuel cell, PV \& fuel cell and wind \& PV \& fuel cell)

PV and Fuel cell doesn't present any optimal solution.

The most optimum combination is wind, PV and diesel with lowest net present cost and energy cost so load shedding was 
applied at the peak load to reduce twenty percent, which results in reducing the net present cost from $\$ 112014$ to $\$ 107880$ and reduce the energy cost from $\$ / \mathrm{KW} 0.284$ to $\$ / \mathrm{KW} 0.275$, the system architecture changed from: $11 \mathrm{KW}$
$\mathrm{PV}$, I wind turbine, $2 \mathrm{KW}$ diesel generator and 30 battery unit to $12 \mathrm{KW} \mathrm{PV}, 1$ wind turbine, $3 \mathrm{KW}$ diesel generator and 28 battery unit.

\section{Table.7: Comparison between Different Hybrid Combinations}

\begin{tabular}{|c|c|c|c|}
\hline System & Architecture & Net Present Cost $(\$)$ & Cost of energy (\$/kwh) \\
\hline Wind and Diesel & $\begin{array}{l}\text { 1BWC WT } \\
4 \mathrm{KW} \text { generator } \\
\text { 10L16P battery } \\
4 \mathrm{KW} \text { converter }\end{array}$ & 131371 & 0.335 \\
\hline PV and Diesel & $\begin{array}{l}20 \mathrm{KW} \text { PV } \\
2 \mathrm{KW} \text { generator } \\
50 \mathrm{~L} 16 \mathrm{P} \text { battery } \\
6 \mathrm{KW} \text { converter }\end{array}$ & 117664 & 0.299 \\
\hline PV and Wind & $\begin{array}{l}20 \mathrm{KW} \text { PV } \\
\text { 1BWC WT } \\
50 \mathrm{~L} 16 \mathrm{P} \text { battery } \\
10 \mathrm{KW} \text { converter }\end{array}$ & 115701 & 0.297 \\
\hline PV, Wind and Diesel & $\begin{array}{l}\text { 11KW PV } \\
\text { 1BWC WT } \\
\text { 2KW generator } \\
30 \text { L16P battery }\end{array}$ & 112014 & 0.284 \\
\hline Wind and Fuel Cell & $\begin{array}{l}6 \mathrm{BWC} \mathrm{WT} \\
6 \mathrm{KW} \mathrm{FC} \\
10 \mathrm{KW} \text { Converter } \\
10 \mathrm{KW} \text { Electrolyzer } \\
20 \mathrm{Kg} \text { Hydrogen Tank }\end{array}$ & 245000 & 0.915 \\
\hline PV and Fuel Cell & No Optimal Solution & No Optimal Solution & No Optimal Solution \\
\hline Wind, PV and Fuel Cell & $\begin{array}{l}2 \mathrm{BWC} \text { WT } \\
40 \mathrm{KW} \mathrm{PV} \\
6 \mathrm{KW} \mathrm{FC} \\
10 \mathrm{KW} \text { Converter } \\
10 \mathrm{KW} \text { Electrolyzer } \\
10 \mathrm{Kg} \text { Hydrogen Tank }\end{array}$ & 160400 & 0.626 \\
\hline
\end{tabular}

\section{REFERENCES}

[1] Mohamed El Badawe, Tariq Iqbal \& George K. Mann, (2012) "OPTIMIZATION AND A COMPARISON BETWEEN RENEWABLE AND NONRENEWABLE ENERGY SYSTEMS FOR A TELECOMMUNICATION SITE”, 25th IEEE Canadian Conference on Electrical and Computer Engineering (CCECE).

[2] El Badawe \& M. Iqal T George M, (2011) "Optimal sizing and modeling of a hybrid energy system for a remote telecommunication facility "presented at IEEE 21 NECEC conference St ohn's NF.

[3] Ross M, Hidalgo R \& Abbey C, Joos G, (2010) "Analysis of Energy Storage sizing and technologies" Electric Power and Energy Conference (EPEC), vol., no., pp.1-6, 2527Aug.2010.

[4] P. Nema et al, (2009)"A current and future state of art development of hybrid energy system using wind and PV-solar: A review." Renewable and Sustainable Energy Reviews 13, 2096-2103.

[5] Wind turbine manufacturer [Online]. Available at http://msmelectric.com/montage/catalog/.
[6] Photovoltaic panels manufacturer [Online]. Available at http://www.wholesalesolar.com/products.

[7] Manufacture and worldwide distributor of long-lasting deep-cycle batteries [Online]. Available at www.trojanbattery.com.

[8] BolfazlShiroudi \& Seyed Reza HosseiniTaklimi, (2011) "Demonstration project of the solar hydrogen energy system loc Taleghan-Iran: Technical-economic assessments" World Renewable Energy Congress Sweden

[9] Souissi Ahmed \& Hasnaoui Othman \& SallamiAni,(2010) "Optimal Sizing of a Hybrid System of Renewable Energy for a Reliable Load Supply without Interruption" European Journal of Scientific ResearchISSN 1450-216X Vol.45 No.4,pp.620-629

[10] NASA Surface Meteorology and Solar Energy [Online]. Available at http://www.nasa.gov

[11] Sureshkumar, Manoharan, P.S. ; Ramalakshmi,(2012) "Economic cost analysis of hybrid renewable energy system using HOMER" IEEE- International Conference On Advances In Engineering, Science And Management (ICAESM -2012) March 30, 31, 2012 